\title{
Soils from HNV agriculture systems as source of microorganisms with antifungal activity
}

\author{
Matei Sorin*, Matei Gabi-Mirela and Dumitrașcu Monica
}

\begin{abstract}
Soils from rural zones with high natural value (HNV) agriculture systems are an important source of beneficial microbial species that can be useful for various biotechnological purposes, such as transfer of suppressiveness against plant pathogens from suppressive to disease-inducing soils by using inoculation with antagonistic selected strains.

The main goal of the paper was to present the results of the research carried out on strains isolated from soil microbial populations in HNV agriculture system (Mureș county, Romania) responsible for specific suppressiveness against soil-borne phytopathogens. The dual culture method was used for assessing the mechanisms involved in antagonism against a plant pathogenic strain from genus Fusarium.

The global microbial activity measured as soil respiration was intense. Total counts of bacteria and fungi estimated by dilution plate were also high.

The community of heterotrophic aerobic bacteria included 13 species. Associations of fluorescent pseudomonads and actinomycetes were dominant and presented antagonistic activity against Fusarium.

Twenty fungal species presented cellulolytic capability evidenced by growth on culture media with cellulose as sole source of carbon. Over cellulolytic capacity, the selected isolate of Trichoderma viride presented antagonistic activity against pathogenic Fusarium strain. Both biochemical mechanism and hyperparasitism were evidenced as involved in its antifungal activity.
\end{abstract}

Keywords: microorganisms, antagonistic activity, Trichoderma viride, phytopathogenic Fusarium, soil suppressiveness

National RD Institute for Soil Science, Agrochemistry and Environment, Bucharest, Romania

*Corresponding author: M. Sorin E-mail: so_matei602003@yahoo.com DOI: 10.2478/ebtj-2018-0049
C 2018 Authors. This work was licensed under the Creative Commons AttributionNonCommercial-NoDerivs 3.0 License.

\section{Introduction}

Agriculture of high natural value (HNV- High Natural Value) represents a recent (last two decades) concept describing those agricultural systems with practices allowing preservation of high biodiversity in Europe. This concept recognizes that preservation of biodiversity depends on traditional agricultural practices but also on applying specific agricultural practices in large zones of rural European space.

The soils in these HNV systems are an important source of beneficial microbial species that can be useful for various biotechnological purposes, such as transfer of suppressiveness against plant pathogens from suppressive to disease-inducing soils by using inoculation with specific selected strains.

Fluorescent and non-fluorescent species of Pseudomonas, actinomycetes, endosporeforming bacteria, fungi from genera Trichoderma, Gliocladium are known as responsible for inhibition of plant pathogens by various mechanisms $(1,2)$.

The goal of the present paper was to present the results of the research carried out on bacteria and fungi isolated from soil microbial populations in high natural value agriculture system (Mureș county, Romania) responsible for specific suppressiveness against soil-borne phytopathogen Fusarium and to assess the antagonistic capacity of Trichoderma strain in order to be selected as performant bioinoculants. 


\section{Materials and Methods}

Soil location: Soil samples $(0-20 \mathrm{~cm})$ collected from high natural value (HNV) agriculture system, habitat 6210, Pilot area 1, Apold, Mureș county, belonging to European network of protected areas, Nature 2000(NGO property), $524 \mathrm{~m}$ altitude, $46^{\circ} 8^{\prime} 4^{\prime \prime} \mathrm{N}$ latitude and $24^{\circ} 49^{\prime} 16^{\prime \prime} \mathrm{E}$ longitude, under grassland without anthropic intervention ( $\mathrm{pH}-8.39$, humus-4.02\%, $\mathrm{N}_{\mathrm{t}}-0.125 \%, \mathrm{~N}_{-} \mathrm{NO}_{3}-7 \mathrm{mg}$ $\mathrm{x} \mathrm{kg}^{-1}, \mathrm{P}_{\mathrm{AL}}-15 \mathrm{mg} \mathrm{x} \mathrm{kg}^{-1}, \mathrm{~K}_{\mathrm{AL}}-205 \mathrm{mg} \mathrm{x} \mathrm{kg}^{-1}$ ).

Microbiological analysis of soil sampled in September 2017, after hay harvesting from high natural value farming system was performed by plating soil decimal dilutions on specific solid culture media, Topping for heterotrophic aerobic bacteria, Czapek for fungi and Stapp for cellulolytic microorganisms.

After 7 days incubation at dark, microbial colonies developed were counted and their density was reported to gram of dry soil.

Taxonomic identification of bacteria was done according to Bergey's manual (3).

Fungi identified according to Domsch and Gams (4) and Watanabe (5) determinative manuals on the basis of colony morphology and structural characteristics observed by optic microscopy.

The global physiological activities of microflora were determined by substrate induced respiration method (SIR) and expressed as $\mathrm{mg} \mathrm{CO} \mathrm{CO}_{2} 100 \mathrm{~g}^{-1}$ soil (6).

According to the Methodology of microbiological analysis utilized in Romanian soil monitoring system (6), values obtained were interpreted following the criteria:

Total bacteria counts

$<10 \times 10^{6}$ viable cells $\mathrm{x} \mathrm{g}^{-1}$ dry soil - low number

$10-20 \times 10^{6}$ viable cells $\mathrm{x} \mathrm{g}^{-1}$ dry soil - moderate number
$>20 \times 10^{6}$ viable cells $\mathrm{x} \mathrm{g}^{-1}$ dry soil - high number

Total fungal counts

$<50 \times 10^{3}$ cfus $\times$ g $^{-1}$ dry soil - low number

$50-100 \times 10^{3}$ cfus $\times$ g $^{-1}$ dry soil - moderate number

100 - $200 \times 103$ cfus x g ${ }^{-1}$ dry soil - high number

$>200 \times 10^{3}$ cfus $\mathrm{x} \mathrm{g}^{-1}$ dry soil - very high number

\section{Soil respiration}

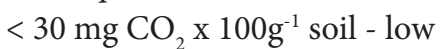

30-80 $\mathrm{mg} \mathrm{CO}_{2} \times 100 \mathrm{~g}^{-1}$ soil - moderate

$>80 \mathrm{mg} \mathrm{CO}_{2} \times 100 \mathrm{~g}^{-1}$ soil - high

\section{Antagonistic activity of microbial strains against Fusarium pathogen}

The microbial antagonistic capacity and mechanisms involved were assessed by dual culture method (7) against soil-borne plant pathogenic strain from genus Fusarium. Colonies were monitored for morphological characteristics, sporulation, production of metabolites and the presence of interaction zone.

Micrographs were done to reveal by optical microscopy the aspects of antagonism and its nature.

\section{Results}

\section{Microbiological analysis}

Quantitative assays (total counts and global microbial activities) Total microbial activity measured as soil respiration was 82.590 mg CO${ }_{2}$ x $100 \mathrm{~g}^{-1}$ soil.

The total counts estimated by dilution plate method were $38.815 \times 10^{6}$ viable cells $\mathrm{x} \mathrm{g}^{-1}$ dry soil for heterotrophic aerobic bacteria and $179.968 \times 10^{3}$ colony forming units $\mathrm{x} \mathrm{g}^{-1}$ dry soil for microscopic fungi.

Table 1. Taxonomic composition of bacterial and fungal microflora in soil from Apold

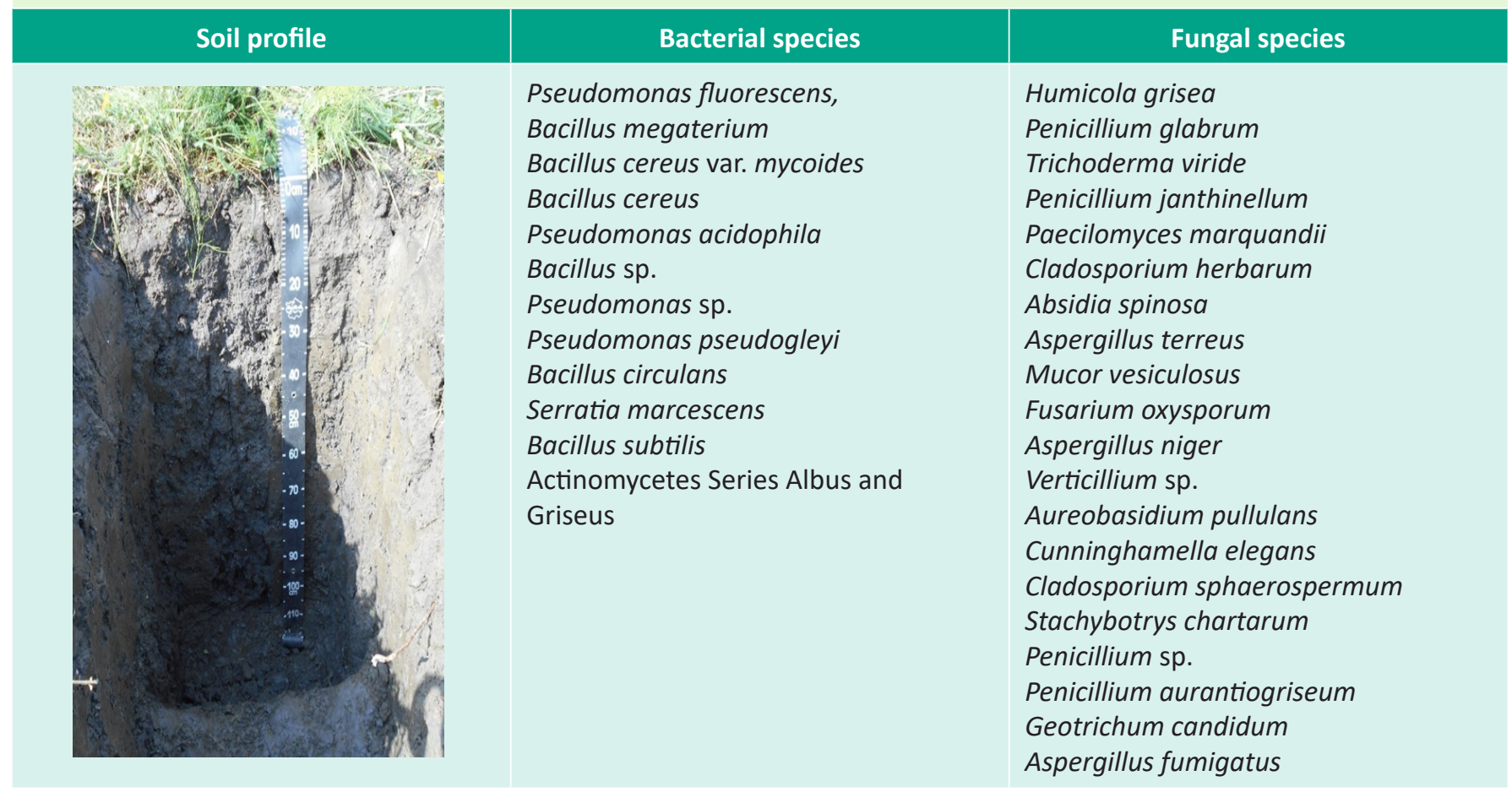




\section{Taxonomic composition of soil microbial communities}

Bacterial community included 13 species, dominated by fluorescent pseudomonads and actinomycetes from series Albus with antagonistic activity against mycotoxigenic strains of Fusarium, accompanied by representatives of genera Bacillus and Serratia (Table 1).

A number of 20 fungal species were identified (Table 1), known for their large adaptability and metabolic ability to decompose various substrates.

Many strains presented the ability to grow on Stapp culture media with cellulose as sole source of carbon (e.g. from genera Stachybotrys, Aspergillus, Cladosporium, Cunninghamella, Paecilomyces, Penicillium, Humicola).

\section{Antagonistic activity of microbial strain against Fusarium pathogen}

Over cellulolytic capacity (Fig. 2), the isolate of Trichoderma viride presented antagonistic activity against Fusarium strain with both biochemical mechanism and hyperparasitism involved, as evidenced by macroscopic and optic microscopy examination of interaction zone (Fig. 1 and Fig. 3).

Morphology and sporulation pattern of phytopathogen were modified (development and sporulation delays, hyphal twisting).

Hyperparasitism was evidenced when Trichoderma developed its own structures around the hyphae of pathogen, emitted haustoria inside it to feed and formed pustules that overgrew Fusarium colony.

Biochemical interaction was revealed by the existence of yellow metabolites more intensely released in the inhibition zone, well visible on the back side of the Petri dish.

\section{Discussion}

The results of the research carried out demonstrated the existence of microbial species diversity in soil from HNV agriculture system (Apold, Mureș county), including thirteen bacterial and twenty fungal taxa. The isolate of Trichoderma viride with high cellulolytic abilities presented antagonistic activity against phytopathogenic Fusarium strain.

Our results are in concordance with data from research carried out on Trichoderma strains showing antifungal activity against various plant pathogens including Fusarium ( 8, 9, 10).

Results from literature reported that biocide formulations with antimicrobial metabolic components extracted from Trichoderma viride alone or from combinations with other fungi were efficient in reducing disease incidence and activating defense response of tomato plants against pathogens (11).

As shown in images of optic microscopy captured in interaction zone between the strains of Trichoderma and Fusarium from dual culture, the metabolites of antagonist visible on the reverse of Petri plate suppressed the growth and fructification of pathogen.

Later, the colony of Trichoderma viride overgrew Fusarium, forming haustoria, pustules and feeding with the content of Fusarium hyphae by enzymatic lysis of the walls.

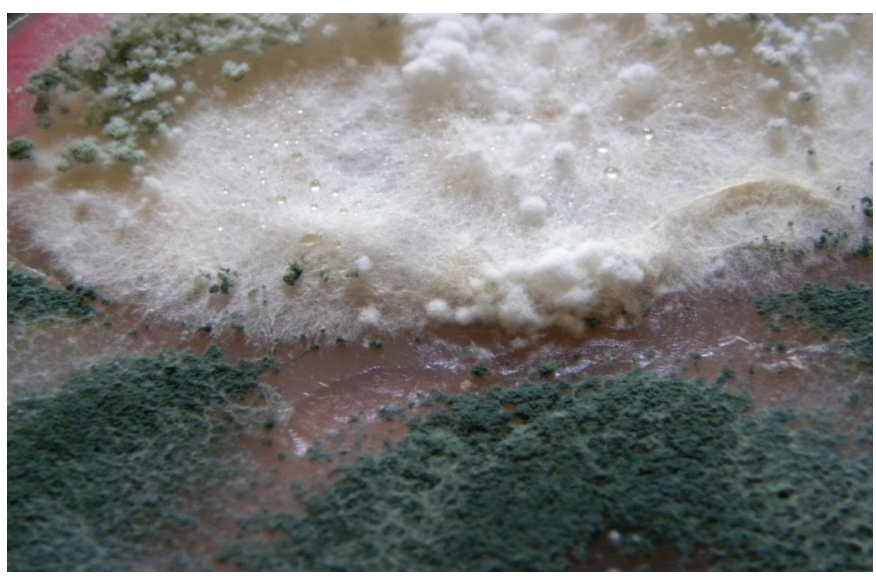

Figure 1. Interaction zone with Fusarium overgrown by Trichoderma viride.

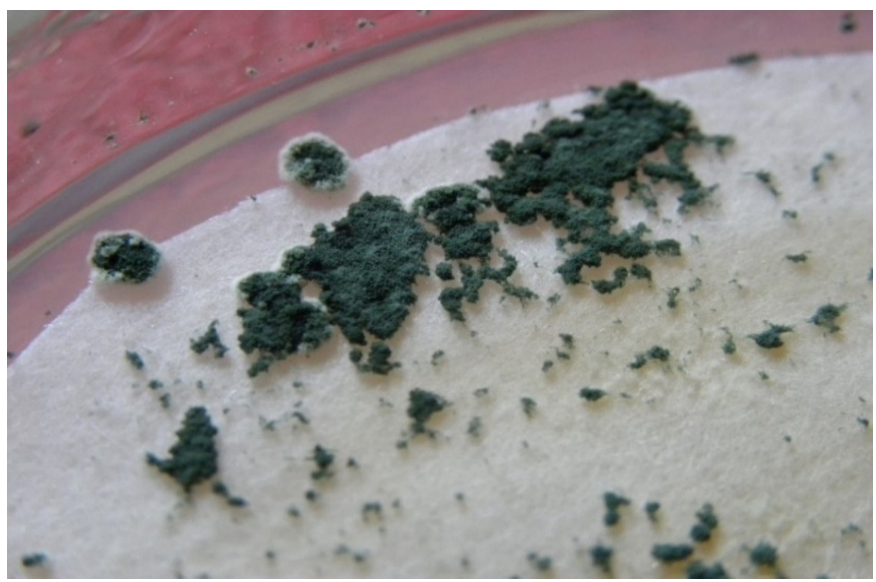

Figure 2. The cellulolytic capacity of Trichoderma viride evidenced by growth on Stapp medium with filter paper as sole source of carbon.

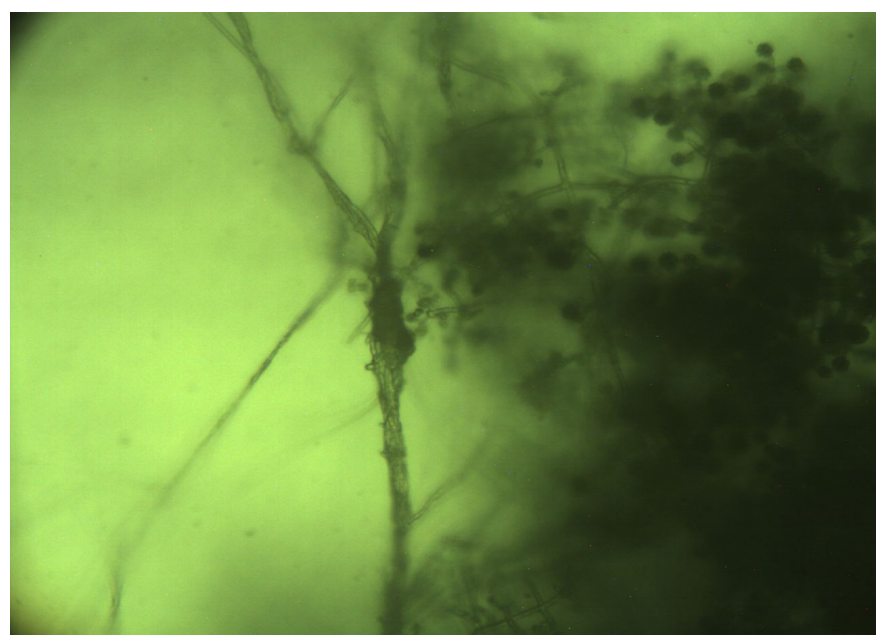

Figure 3. Hyphae and haustoria of Trichoderma viride hyperparasite on Fusarium hyphae.

Similar results with hyperparasitism and biochemical antagonism involved were reported for various Trichoderma strains that showed significant inhibitory effect against fungal pathogenic species $(12,13)$.

As in our previous research (14) with Trichoderma viride 
strain SP456 that inhibited Botrytis cinerea, literature cites research with biopreparations of Trichoderma strains (e.g. Trichoderma harzianum-T22, well-known under commercial brand Root Shield) for the biocontrol of pathogenic fungi and explain their inhibitory properties by the ability to produce various enzymes and metabolites from the group of trichothecenes with antifungal properties (15).

Results of the present work evidenced the antifungal activity of Trichoderma viride isolated from soil in HNV agriculture system from Apold by biochemical antagonism and hyperparasitism and recommend it for utilization in biotechnological strategies of suppressiveness transfer against phytopathogenic fungi from genus Fusarium.

\section{Conclusions}

The well-developed and active microbial populations from soil in high natural value system under grassland, with 13 bacterial and 20 fungal taxa were dominated by fluorescent pseudomonads, actinomycetes and included many cellulolytic species of fungi.

Trichoderma viride presented cellulolytic and antagonistic activity against Fusarium strain with both biochemical mechanism and hyperparasitism involved.

Morphology and sporulation pattern were modified (delays, discoloration) and biochemical interaction was revealed by the existence of yellow metabolites more intensely released in the inhibition zone.

Hyperparasitism was evidenced when Trichoderma developed its own structures around the hyphae of pathogen Fusarium, emitted haustoria inside to feed and formed pustules.

Results of in vitro assays recommend the Trichoderma viride strain for biotechnological purposes, as antifungal agent in soil inoculation with microbial consortia for the transfer of suppressiveness against pathogen Fusarium.

\section{Acknowledgements}

This work was supported by project PN NUCLEU $184403 \quad 02$ : Analysis of sensitivity of edaphic indicators from the high natural value agriculture system and of stake holders vision on the impact of agro-environmental practices, soil protection politics and related societal challenges.

\section{Conflict of interest statement}

The authors declare that they have no conflict of interest.

\section{References}

1. McQuilken MP, Gemmmel J, Lahdenpera ML. Gliocladium catenulatum as a potential biocontrol agent of damping-off in bedding plants. J Phytopathol 2001; 149: 171-178.

2. Hassan S, Gupta G, Anand S, Chaturvedi A, Kaur H. Biopotential of microbial antagonists against soil borne fungal plant pathogens. Int J Agr Food Sci Technol 2013; 4(2): 37-39.

3. Bergey DH, Holt JG. Bergey's manual of determinative bacteriology 9. Williams \& Wilkins Eds., Baltimore 1994.

4. Domsch KH, Gams W. Fungi in agricultural soils. T\&A Constable Ltd. Edinburg, London 1970.

5. Watanabe T. Pictorial Atlas of Soil and Seed Fungi: Morphologies of Cultured Fungi and Key to Species $2^{\text {nd }}$ ed. 2002; CRC PRESS.

6. Matei S. Determination of soil respiration and microbial biomass. In: Dumitru M, Manea A(coord). Methods of chemical and microbiological analysis (utilized in soil monitoring system), (in Romanian). Ed. SITECH, Craiova 2011; p. 283-288.

7. Phuoc NT. Biological control of tomato root and stem rot caused by Sclerotinium rolfsii Sacc., ARC Training, 1988 Report-Tomato, $p$. $1-11$.

8. Rini CR, Sulochana KK. Usefulness of Trichoderma and Pseudomonas against Rhizoctonia solani and Fusarium oxysporum infecting tomato. Jpn J Trop Agr 2007; 45: 21-28.

9. Shahid M. Evaluation of antagonistic activity and shelf life study of Trichoderma viride (01-PP-8315/11). Adv In Life Sci 2012; 1: 138140.

10. Matarese F, Sarrocco S, Gruber S, Seidl-Seiboth V, Vannacci G. Biocontrol of Fusarium head blight: interactions between Trichoderma and mycotoxigenic Fusarium. Microbiol 2012; 158: 98-106.

11. Mitra J, Bhuvaneshwari V, Paul PK. Broad spectrum management of plant diseases by phylloplane microfungal metabolites. Arch Phytopatol Plant Prot 2013; http://dx.doi. org/1080/03235408.2013.782648

12. Kukuc C, Kivanc M. Isolation of Trichoderma spp. and determination of their antifungal, biochemical and physiological features. Turk J Biol 2003; 27: 247-253.

13. Zeilinger S, Osmann M. Trichoderma biocontrol:signal transduction pathways involved in host sensing and mycoparasitism. Gene Reg Sys Biol 2007; 1: 227-234.

14. Matei GM, Matei S, Mocanu V, Dumitru S. Microbiological characterization of suppressive forest soil from Enisala, Ann Univ Craiova, Agr Montan Cad 2016; 46: 341-347.

15. Montes E. Understanding Trichoderma between biotechnology and microbial ecology. Int Microbiol 2001; 4: 1-4. 